https://helda.helsinki.fi

\title{
Airborne bacteria and carcass contamination in slaughterhouses
}

Rahkio, T.

International Association for Food Protection

1997

Journal of food protection. 1997. 60: 38-42

http://hdl.handle.net/1975/760

Downloaded from Helda, University of Helsinki institutional repository.

This is an electronic reprint of the original article.

This reprint may differ from the original in pagination and typographic detail.

Please cite the original version. 


\title{
Airborne Bacteria and Carcass Contamination in Slaughterhouses
}

\author{
T. MARJATTA RAHKIO* and HANNU J. KORKEALA \\ Department of Food and Environmental Hygiene, University of Helsinki, P.O. Box 57, FIN-00014 Helsinki University, Finland
}

(MS\# 95-229: Received 14 September 1995/Accepted 14 May 1996)

\begin{abstract}
Microbiological contamination of air and carcasses was studied in four slaughterhouses by using impactor samples taken at the back-splitting and weighing areas and by sampling carcasses with the swabbing method. Air flow was determined by an air-flow detector, and the movement of workers was observed. The air contamination level in the back-splitting areas (2.25 log CFU/100 liters of air) was generally higher than that in the weighing areas ( $2.03 \log$ CFU/100 liters of air). Associations between the microbiological contamination of air and carcasses with the movements of workers were found. Layout of the slaughtering line was shown to be important in decreasing airborne contamination. Separation of the clean and unclean parts of the line as well as separation of the weighing area from the other clean parts of the line decreased the contamination level. It appears that airborne bacteria have an important role in carcass contamination.
\end{abstract}

Key words: Air contamination, hygiene, swabbing method, pork, beef, air flow, impactor, slaughterhouse

Airborne contamination of dairy plants has been considered very important by the dairy industry $(6,7,8,22,23)$. The air contamination level in meat plants during processing has also been investigated $(10,16,17,18,30)$ and the results indicate that airborne microbes are a potential source of microbiological contamination in meat products.

In spite of the possible role of airborne microbes in the microbiological contamination of meat products, to the author's knowledge, no data have been published on the associations between microbiological contamination of pork carcasses and airborne bacteria during slaughtering. Furthermore, only limited information is available $(3,25)$ on the associations between beef-carcass contamination and airborne bacteria during slaughtering. Sirami $(25)$ found associations between airborne bacteria and the contamination level of beef carcasses. Airborne contamination in the beef slaughtering hall decreased towards the weighing area and increased towards the weekend. No changes related to working hours were detected.

\footnotetext{
* Author for correspondence. Tel: 358-9-70849712; Fax: 358-9-70849718.

E-Mail: Marjatta.Rahkio@EV.Kuluttajatalo.mailnet.Fi
}

The purpose of this study was to report the level of airborne bacteria in pork and beef slaughterhouses as well as to examine the association between the number of airborne bacteria and carcass contamination level.

\section{MATERIALS AND METHODS}

\section{Air sampling}

Air samples of bacteria were taken in four slaughterhouses (A, B, C, D) during a 2-week period at each plant. Air samples were taken at a height from 1 to $1.5 \mathrm{~m}$ from the floor within $1 \mathrm{~m}$ of the carcasses at the back-splitting and weighing areas of beef and pork lines. The samples were taken by using an Andersen Two-Stage Viable Particle Sizing Sampler (Andersen Sampler Inc., Atlanta, GA, USA) at a flow rate of $0.0283 \mathrm{~m}^{3} / \mathrm{min}$ (1) with a sampling time of $4 \mathrm{~min}$. The sampler was cleaned prior to use according to the method of Sveum et al. (29). Two 9-cm-diameter petri dishes containing $20 \mathrm{ml}$ of plate count agar (Difco Laboratories, Detroit, MI, USA) were placed into the impactor. Air samples were taken between 9 a.m. and 2 p.m. Samples taken from 9 to 11:30 a.m. were assessed as morning samples, and those taken from 12 to 2 p.m. as afternoon samples. When analyzing the relationship between the airborne bacteria and carcass contamination, the level of airborne bacteria was calculated as a mean of three consecutive determinations performed from the same area.

Air flow of beef and pork lines in each slaughterhouse was determined twice by Dräger air-current tubes (Drägerwerk AG, Lübeck, Germany). The areas between the lairage and stunning area and between the unclean and clean parts of the line were studied. The clean part of the line started after skinning in the beef line and after scalding and polishing in the pork line. This division between the unclean and clean parts of the line was determined according to Snijders et al. (26).

\section{Carcass sampling}

Carcasses were sampled after slaughter at weighing before chilling in the same four slaughterhouses. In order to avoid variation in the swabbing technique all samples were taken by the same person. Samples were taken from the neck and abdomen of pork carcasses and from the brisket and shoulder of beef carcasses. The samples were taken by the moisture swab technique of Lasta and Fonrouge (13), using a sampling area of $25 \mathrm{~cm}^{2}$; the first dilution volume was $25 \mathrm{ml}$ (dilutions were made in physiological saline). Six to 10 pork and beef carcasses were sampled daily. In slaughterhouse $A, 12$ pork carcasses, in B, 16 pork and 22 beef, in $\mathrm{C}, 20$ pork, and in D, 10 pork and beef carcasses were sampled. The 
total number sampled amounted to 58 pork carcasses and 32 beef carcasses. Carcasses were sampled within $2 \mathrm{~h}$ of the air samplings.

\section{Microbiological methods}

Total bacterial counts were determined according to Rahkio et al. (21). Final airborne bacterial counts were estimated by means of the "positive hole" correction (14).

\section{Movement of workers}

After sampling, the movements of workers between the clean and unclean parts of the line were recorded on a 2-point scale as either moving or not moving during the 15 -min observation period. Workers were observed by the same person. The number of workers observed in the pork and beef lines of the four slaughterhouses A, B, C, and D was 15, 24, 10, and 14, respectively. The total number of workers observed was 63 .

\section{Statistical analysis}

Statistical analyses of airborne bacteria were carried out by the 2-sample $t$-test and GLM (general linear model) of the Statistical Analysis System (27). Whenever a GLM produced a statistically significant difference for a variable, Duncan's multiple range test was used to perform simultaneous comparisons of the levels of the variable. The comparisons of airborne bacteria with carcass contamination were carried out by using Pearson's correlation test and Friedman's rank-order analysis of variance (28). All statistical tests for bacterial counts were performed with log transformations.

\section{RESULTS}

Table 1 shows the airborne bacterial counts of air for the pork and beef lines of the four slaughterhouses. When the air contamination counts from back-splitting and weighing areas in the pork lines were summarized and analyzed together, the lowest mean air contamination level in a pork line was detected at slaughterhouse B (1.8 log CFU/100 liters of air) and the highest (2.83 $\log$ CFU/100 liters of air) at slaughterhouse $\mathrm{C}$. In beef lines, the lowest air contamination level was encountered at slaughterhouse B (1.21 log CFU/100 liters of air) and the highest at slaughterhouse A (2.88 log CFU/100 liters of air), respectively. Air in the back-splitting area of the pork line had the highest contamination level compared to the other areas.

There were no differences between the airborne bacterial counts determined in the morning (2.18 log CFU/100
TABLE 2. Regression analysis for airborne bacteria as a dependent variable $\left(\mathrm{R}^{2}=0.64\right)$

\begin{tabular}{lcrrr}
\hline $\begin{array}{l}\text { Independent } \\
\text { predictor variable }\end{array}$ & $\begin{array}{c}\text { Degrees of } \\
\text { freedom }\end{array}$ & $\begin{array}{r}\text { Sum of } \\
\text { squares }\end{array}$ & $F$ value & $P$ value \\
\hline Sampling time & 1 & 0.00 & 0.00 & 0.939 \\
Line & 1 & 0.00 & 0.00 & 0.983 \\
Sampling area & 1 & 3.58 & 17.34 & $0.000^{* * * a}$ \\
Slaughterhouse & 3 & 33.94 & 54.81 & $0.000^{* * *}$ \\
Sampling area by line & 1 & 1.49 & 7.23 & $0.008^{* *}$ \\
Slaughterhouse by line & 3 & 5.47 & 8.84 & $0.000^{* * *}$ \\
\hline
\end{tabular}

$a * * P<0.01 ; * * * P<0.001$.

liters of air) and afternoon (2.07 log CFU/100 liters of air) or between pork (2.21 log CFU/100 liters of air) and beef ( 2.08 $\log$ CFU/100 liters of air) lines according to the regression analysis (Table 2). The regression analysis revealed different bacterial counts in air in the sampling areas and slaughterhouses. Samples from the back-splitting areas (2.25 log CFU/100 liters of air) had significantly higher bacterial counts than those from the weighing areas (2.03 log CFU/100 liters of air) according to Duncan's test $(P<0.001)$. Although no differences in the bacterial counts in air between beef and pork lines were revealed by the regression analyses, an interaction between line and area and between line and slaughterhouse was found. According to the data in Table 1, it may be concluded that the differences in the airborne bacterial counts between weighing and splitting sampling areas were greater in pork than in beef lines, while between slaughterhouses they were greater in beef than in pork lines.

It was found that the direction of airflow was from the slaughtering hall to the lairage in the pork and beef lines of all the slaughterhouses studied with the exception of slaughterhouse $\mathrm{C}$, where it flowed in the opposite direction.

The direction of airflow between the unclean and clean parts of the line could not be clearly determined in most of the lines studied. Air either flowed slowly towards the floor or across the slaughtering line. Airflow from the clean to unclean parts of the lines was encountered only in the pork lines of slaughterhouses B and D.

The means of carcass contamination in different slaughterhouses varied from 2.40 to $3.52 \log \mathrm{CFU} \mathrm{cm} \mathrm{cm}^{-2}$ in pork and from 1.44 to $2.61 \log \mathrm{CFU} \mathrm{cm^{-2 }}$ in beef carcasses. Table

TABLE 1. Airborne bacteria in two areas of beef and pork lines in four slaughterhouses

Airborne bacteria: mean $\log \mathrm{CFU} / 100$ liters of air $\pm \operatorname{SD}(n)$

\begin{tabular}{|c|c|c|c|c|c|}
\hline \multirow[b]{3}{*}{ Slaughterhouse } & \multicolumn{5}{|c|}{ Airborne bacteria: mean log CFU/100 liters of air $\pm \mathrm{SD}(n)$} \\
\hline & \multicolumn{2}{|c|}{ Pork line } & \multicolumn{2}{|c|}{ Beef line } & \multirow[b]{2}{*}{ Total } \\
\hline & Back-splitting area & Weighing area & Back-splitting area & Weighing area & \\
\hline A & $2.24 \pm .52 \mathrm{MNX}^{a}(6)$ & $2.21 \pm .17 \mathrm{NX}(7)$ & $2.71 \pm .60 \mathrm{NX}(4)$ & $3.01 \pm .27 \mathrm{PX}(6)$ & $2.51 \pm .460(23)$ \\
\hline B & $2.14 \pm .23 \mathrm{MY}(12)$ & $1.46 \pm .42 \mathrm{Mx}(12)$ & $1.22 \pm .82 \mathrm{MX}(15)$ & $1.21 \pm .18 \mathrm{Mx}(9)$ & $1.50 \pm .64 \mathrm{M}(48)$ \\
\hline $\mathrm{C}$ & $3.08 \pm .42 \mathrm{OY}(9)$ & $2.58 \pm .48 \mathrm{NX}(9)$ & $2.65 \pm .20 \mathrm{NX}(9)$ & $2.59 \pm .330 \times(9)$ & $2.72 \pm .410(36)$ \\
\hline D & $2.46 \pm .33 \mathrm{NY}(9)$ & $1.73 \pm .39 \mathrm{MX}(8)$ & $2.51 \pm .62 \mathrm{NX}(9)$ & $2.00 \pm .30 \mathrm{NX}(9)$ & $2.19 \pm .53 \mathrm{~N}(35)$ \\
\hline All & $2.47 \pm .37 Y(36)$ & $1.94 \pm .39 \times(36)$ & $2.04 \pm .64 \times(37)$ & $2.13 \pm .28 \times(33)$ & $2.15 \pm .73(142)$ \\
\hline
\end{tabular}

${ }^{a}$ Means within a column followed by different letters (M, N, O, P) and means within a row followed by different letters (X, Y) are significantly different $(P<0.05)$. 
TABLE 3. Correlations between air contamination (log CFU/100 liters of air) and bacterial carcass contamination (log $\left.\mathrm{CFU} \mathrm{cm}{ }^{-2}\right)$

Correlation $(r)$

\begin{tabular}{llll}
\hline & \multicolumn{3}{c}{ Correlation $(r)$} \\
\cline { 2 - 4 } & \multicolumn{3}{c}{ Area of air sampling $(n)$} \\
\cline { 2 - 4 } $\begin{array}{l}\text { Area of } \\
\text { carcass sample }\end{array}$ & Back-splitting area & Weighing area & Both areas \\
\hline Pork & & & \\
$\quad$ Neck & $0.718(4)$ & $0.929(7)^{* * a}$ & $0.799(7)^{* a}$ \\
Abdomen & $0.738(4)$ & $0.747(7)$ & $0.594(7)$ \\
$\quad$ Both sites & $0.655(8)$ & $0.810(14)^{* *}$ & $0.683(14)^{* *}$ \\
Beef & & & \\
$\quad$ Shoulder & $0.888(4)$ & $0.949(4)^{*}$ & $0.926(4)$ \\
$\quad$ Brisket & $0.736(4)$ & $0.909(4)$ & $0.818(4)$ \\
$\quad$ Both sites & $0.780(8)$ & $0.890(8)^{* *}$ & $0.837(8)^{* *}$ \\
All & $0.786(16)^{* *}$ & $0.816(22)^{* *}$ & $0.791(22)^{* *}$ \\
\hline
\end{tabular}

$a * P<0.05 ; * * P<0.01$.

3 shows the correlations between air and carcass contamination. Contamination levels of both pork and beef carcasses were clearly associated with airborne contamination level, especially that in the weighing area. Contamination of pork neck and beef shoulder appeared to be more clearly associated with the bacterial counts in the air than the contaminations of abdomen in pork and brisket in beef carcasses.

Table 4 gives the mean ranks of four slaughterhouses by air and carcass contamination. According to the results, the mean bacterial counts in the air and on carcasses ranked each slaughterhouse similarly.

Movement of workers between the unclean and the clean parts of the line was especially observed on the pork line of slaughterhouse $\mathrm{C}$ and the beef line of slaughterhouses A and D. Levels of pork-carcass contamination found in slaughterhouses where workers moved between different parts of the line (A and $C$ ) and in those where they did not (B and D) are shown in Table 5. Pork carcasses had significantly $(P<0.05)$ higher contamination levels in those slaughterhouses where workers moved between different parts of the line. The same result was observed for beef carcasses.

TABLE 4. Mean ranks of air contamination and microbiological contamination of carcasses in four slaughterhouses

\begin{tabular}{lccc}
\hline & \multicolumn{3}{c}{ Mean contamination rank ${ }^{a}$} \\
\cline { 2 - 4 } Slaughterhouse & Air & Carcass & Air and carcass \\
\hline A & 3.3 & 3.5 & 11.4 \\
B & 1.0 & 1.0 & 1.0 \\
C & 3.5 & 3.5 & 12.3 \\
D & 2.3 & 2.0 & 5.0 \\
Significance of Friedman's test & 0.02 & 0.14 & $<0.001$ \\
\hline
\end{tabular}

${ }^{a}$ The four slaughterhouses' mean ranks have theoretical values from 1 to 4 in the case of air or carcass contamination ( 1 to 16 for air AND carcass). A value of 4 (16) means that the slaughterhouse had the highest level of the type of contamination indicated (air, carcass, or air and carcass) according to all samples of that type.
TABLE 5. Bacterial counts on pork carcasses according to frequency of workers' movement between unclean and clean parts of line in the slaughterhouses

\begin{tabular}{lccc}
\hline & & \multicolumn{2}{c}{$\begin{array}{c}\text { Mean bacterial counts } \pm \text { SD } \\
\left(\log \mathrm{CFU} \mathrm{cm}^{2}\right)^{a} \text { on: }\end{array}$} \\
\cline { 3 - 4 } $\begin{array}{l}\text { Movement in } \\
\text { slaughterhouses A, B, C, D }\end{array}$ & $\begin{array}{c}\text { Pork } \\
\text { samples }(n)\end{array}$ & Neck & Abdomen \\
\hline No movement (B, D) & $(26)$ & $2.55 \pm .69 \mathrm{~A}$ & $2.81 \pm .65 \mathrm{~A}$ \\
Some movement (A, C) & $(32)$ & $3.76 \pm .49 \mathrm{~B}$ & $3.34 \pm .39 \mathrm{~B}$ \\
\hline${ }^{a}$ Means within a column followed by different letters are signifi- \\
cantly different $(P<0.05)$.
\end{tabular}

\section{DISCUSSION}

Mean airborne bacteria in the back-splitting areas of pork lines were higher than those in the weighing areas of those slaughterhouses (B, C, and D) with long distances between back-splitting and weighing areas for pork. The back-splitting and weighing areas of slaughterhouse A were in very close proximity in both the pork and beef lines. The overall bacterial level of $2.47 \log \mathrm{CFU} / 100$ liters of air of the back-splitting areas for pork is close to the levels that Kotula et al. (11) and Kotula and Emswiler-Rose (10) found in the evisceration area for pork carcasses. The comparatively high level in the back-splitting compared to the weighing area may be due to bacterial transport to the splitting area via airflow from the unclean parts of the lines, in addition to the water and bacteria spread by cutting saws.

According to the present results, the direction of airflow affects air contamination. The airflow between the lairage and slaughtering hall was well directed in all slaughterhouses except for the pork line of slaughterhouse $\mathrm{C}$, which had the highest air contamination level. The lowest air contamination level in weighing areas compared to backsplitting areas was found in the pork lines of slaughterhouses $\mathrm{B}$ and $\mathrm{D}$, where the airflow direction was from the clean to the unclean parts of the pork lines. Obviously, the line layout and the airflow direction affect the air contamination level.

A strong association between carcass and air contamination was observed in the present study. Air is an important bacterial vehicle in slaughterhouses and the present results confirm the assumption of Knudson and Hartman (9) that airborne bacteria can cause contamination during slaughter. The hide or skin of slaughtered animals has been thought to be the source of airborne bacteria in slaughterhouses $(3,20$, $25)$, or a source of carcass bacteria $(19,24)$. Airborne bacteria likely originates from the fur or skin of the animals in lairages or in the unclean part of the line. In the absence of any precautions such as corners, walls, or other means of separation, these bacteria may be moved by the airflow into the clean areas and thus contaminate dehided beef and singed and polished pork carcasses.

The movement of personnel between the clean and unclean parts of the lines appears to be associated with higher carcass contamination level. Frequency of movement was highest in the pork line of slaughterhouse $\mathrm{C}$, where the pork carcasses had the highest contamination level. In beef 
lines the highest frequencies of movement occurred in slaughterhouses A and D, where the contamination level of beef carcasses was the highest. However, on the basis of the findings of this study it is not possible to conclude whether such movement has a direct impact on contamination. The need for frequent movement by personnel is probably due to generally poor line design, which in turn can lead to contamination. Lines with high air-contamination levels had inadequate constructional barriers for the separation of the unclean and clean parts. In slaughterhouse A the pork line was parallel to the beef line until evisceration. Furthermore, there were no walls or other barriers between the clean and the unclean parts of the lines. In slaughterhouse $\mathrm{C}$ the lines were on opposite sides of the slaughtering hall and separated by a wall until weighing. The clean part of the beef line began after the wall turned a corner, whereas in the pork line there was no corner or other barrier between the unclean and clean parts. In slaughterhouse D, the lines were separated up to evisceration by a wall which also separated the clean and unclean parts of the pork line. The beef line had no barriers or other obstacles between the unclean and clean parts of the line. All the lines in slaughterhouse B were completely separated. In addition, separation of the unclean and clean parts was the best and the movement of workers between the parts the least frequent. The importance of separating the clean and unclean parts of the line has long been emphasized $(2,12,26)$. Kotula and Kinner (12) proposed that by use of walls and other separation methods, areas of low and high bacterial counts can be created in poultry plants. Ellenbroek (2) stated that faulty air conduction can destroy the separation of clean and unclean parts during the poultryslaughtering process.

The airborne bacterial count may also offer an alternative method for contamination control of carcasses in slaughterhouses. Several authors have criticized the current methods of carcass sampling and suggested the need for the development of more practical, suitable, and rapid methods for this control $(4,5,13,15)$. Although taking air samples requires special equipment, it is a more convenient and time-saving procedure than carcass sampling. Personnel performing the sampling need not touch the carcasses, nor stop or disturb the line. The use of counts of airborne bacteria for the evaluation of contamination level of carcasses will require further research. However, surface samples as indications of hygiene are very important, because the pathogenic bacteria due to slaughtering errors and fecal contamination can be measured by carcass-surface sampling.

\section{REFERENCES}

1. Anonymous. 1984. Operating manual for Andersen Sampler, Inc. viable (microbial) particle sizing sampler. Andersen Sampler, Inc., Atlanta, GA, USA.

2. Ellenbroek, L. 1994. Airborne contamination of chilling rooms in poultry meat processing plants (Disk S-II B.46). Presented at the 40th International Congress of Meat Science and Technology, The Hague, Netherlands.

3. Fournaud, J., G. Graffino, R. Rosset, and R. Jacque. 1978. Contamination microbienne des carcasses a l'abattoir. Ind. Aliment. Agric. 95:273282.
4. Huis in't Veld, J. H. J., R. W. A. W. Mulder, and J. M. A. Snijders. 1994. Impact of animal husbandry and slaughter technologies on microbial contamination of meat. Monitoring and control. Meat Sci. 36:123-154.

5. Ingram, M., and T. A. Roberts. 1976. The microbiology of the red meat carcass and the slaughterhouse. Roy. Soc. Health J. 96:270-276.

6. Kang, Y.-J., and J. P. Frank. 1989. Biological aerosols: A review of airborne contamination and its measurements in dairy processing plants. J. Food Prot. 52:512-524.

7. Kang, Y.-J., and J. P. Frank. 1989. Evaluation of air samplers for recovery of biological aerosols in dairy processing plants. J. Food Prot. 52:655-659.

8. Kang, Y.-J., and J. P. Frank. 1989. Comparison of airborne microflora collected by the Andersen sieve sampler and RCS sampler in a dairy processing plant. J. Food Prot. 52:877-880.

9. Knudtson, L., and P. H. Hartman. 1993. Enterococci in pork processing. J. Food Prot. 56:6-9.

10. Kotula, A. W., and B. S. Emswiler-Rose. 1988. Airborne microorganisms in a pork processing establishment. J. Food Prot. 12:935-937.

11. Kotula, A. W., J. R. Guilfoyle, B. S. Emswiler, and M. D. Pierson. 1978. Comparison of single and multiple stage sieve samplers for airborne microorganisms. J. Food Prot. 41:447-449.

12. Kotula, A. W., and J. A. Kinner. 1964. Airborne microorganisms in broiler processing plants. Appl. Microbiol. 12:179-184.

13. Lasta, J., and R. Fonrouge. 1988. Significance of samples taken for bacterial counts from reduced areas of bovine carcasses. J. Food Prot. 51:214-217.

14. Leopold, S. S. 1988. Positive hole-statistical adjustment for a two-stage, 200-hole-per-stage Andersen Air Sampler. Am. Ind. Hyg. Assoc. J. 49:A88-90.

15. Mackey, B. M., and T. A. Roberts. 1990. Hazard analysis and critical control point programmes in relation to slaughter hygiene, p. 3-18. In J. Hannan and J. D. Collins (ed.), The scientific basis for harmonising trade in red meat. University College Dublin, College Printing Services, Dublin.

16. Mäkelä, P. 1993. Lactic acid bacterial contamination at meat processing plants. Ph. D. Thesis, The University of Veterinary Medicine, Helsinki, Finland.

17. Mäkelä, P., and H. Korkeala. 1987. Lactobacillus contamination of cooked ring sausages at sausage processing plants. Int. J. Food Microbiol. 5:323-330.

18. Mäkelä, P., H. Korkeala, and J. Laine. 1992. Ropy slime producing lactic acid bacteria contamination at meat processing plants. Int. J. Food Microbiol. 17:27-35.

19. Newton, K. G., J. C. L. Harrison, and A. M. Wauters. 1978. J. Appl. Bacteriol. 45:75-82.

20. Nottingham, P. M., N. Penney, and J. C. L. Harrison. 1974. Microbiology of beef processing. I. Beef dressing hygiene. N. Z. J. Agric. Res. 17:79-83.

21. Rahkio, M., H. Korkeala, I. Sippola, and M. Peltonen. 1992. Effect of prescalding brushing on contamination level of pork carcasses during the slaughtering process. Meat Sci. 32:173-183.

22. Ren, T.-J., and J. F. Frank. 1992. A survey of four fluid milk processing plants for airborne contamination using various sampling methods. J. Food Prot. 55:38-42.

23. Ren, T.-J., and J. F. Frank. 1992. Measurement of airborne contamination in two commercial ice cream plants. J. Food Prot. 55:43-47.

24. Ridell, J., and H. Korkeala. 1993. Special treatment during slaughtering in Finland of cattle carrying an excessive load of dung, meat hygiene aspect. Meat Sci. 35:223-228.

25. Sirami, J. 1989. La contamination microbiologique de l'air dans le hall d'abattage: facteurs de variation et influence sur la carcasse. Viand. Prod. Carnes 10:109-116.

26. Snijders, J. M. A., G. E. Gerats, and J. G. Logtestijn. 1984. Good manufacturing practices during slaughtering. Arch. Lebensmittelhyg. 35:99-103.

27. Statistical Analysis System. 1985. SAS ${ }^{\circledR}$ user's guide: basics, version 5 ed. SAS Institute Inc., Cary, NC, USA. 
28. Statistix. 1992. User's manual, version 4.0 ed. Analytical software, St. Paul, MN, USA.

29. Sveum, W. H., L. J. Moberg, R. A. Rude, and J. F. Frank. 1992. Microbiological monitoring of the food processing environment, $\mathrm{p}$. 51-74. In C. Vanderzant and D. F. Splittstoesser (ed.), Compendium of methods for the microbiological examination of foods. American Public Health Association, Washington, D.C.

30. Takahashi, E., T. Sagi, K. Satomi, and M. Yokoyama. 1989. Studies an airborne microbes in chilled beef processing plant. J. Antibact. Antifung. Agent. 17:565-571. 